WENNECK, G. S.; SAATH, R.; ARAÚJO, L. L.; PEREIRA, G. L.; OLIVEIRA, G. G. F.; SÁ, N. O.; VOLPATO, C. S. Yield and economic analysis of corn and brachiaria intercropping in the northwestern Paraná. Revista de Agricultura Neotropical, Cassilândia-MS, v. 8, n. 4, e6163, out./dez. 2021. ISSN 2358-6303. DOI: https://doi.org/10.32404/rean.v8i4.6163

\title{
Yield and economic analysis of corn and brachiaria intercropping in the northwestern Paraná
}

\author{
Gustavo Soares Wenneck ${ }^{1}$, Reni Saath ${ }^{1}$, Larissa Leite de Araujo ${ }^{1}$, Gustavo Lopes Pereira ${ }^{1}$, \\ Giovanna Gabriela Ferreira de Oliveira ${ }^{1}$, Nathália de Oliveira Sá ${ }^{1}$, Camila de Souza Volpato ${ }^{1}$
}

\footnotetext{
${ }^{1}$ Universidade Estadual de Maringá, Campus de Maringá, Maringá, Paraná, Brasil. E-mail:gustavowenneck@gmail.com, rsaath@uem.br, larissa_leite_araujo@ hotmail.com, gustavolopespereira@ hotmail.com, ra106907@uem.br,

ndeoliveirasa@gmail.com, camila16volpato@gmail.com
}

Received: 07/05/2021; Accepted: 27/09/2021.

\section{ABSTRACT}

The maize and Urochloa ruziziensis intercropping have potential use for agricultural production systems, allowing the production of grains and biomass. The study aims to evaluate the yield and economic viability of corn and $\mathrm{U}$. ruziziensis intercropping modalities in the northwestern region of Paraná. The experiment was conducted in Maringá-PR in a completely randomized design with five treatments (single corn; single $U$. ruziziensis; $U$. ruziziensis between the corn rows; corn with $U$. ruziziensis in the same row; corn rows interspersed with $U$. ruziziensis rows) and four replicates. Initial development, grain yield of corn, and the production of biomass of corn and $U$. ruziziensis were evaluated. The data were submitted to analysis of variance. The means were compared by the Tukey test at 5\% probability. In the initial development of corn plants, there was no significant difference due to intercropping. $U$. ruziziensis in the intercropped system had a reduction in biomass production. Intercropping with corn rows interspersed with $U$. ruziziensis rows had grain yield higher than other intercropping modalities and similar to single corn cultivation

Keywords: Biomass, Grain production, No-Tillage System, Zea mays.

\section{Produtividade e análise econômica do cultivo consorciado de milho e braquiária no noroeste do Paraná}

\section{RESUMO}

A consorciação de milho e Urochloa ruziziensis apresenta potencial para os sistemas de produção agrícola, permitindo a produção de grãos e biomassa remanescente. $\mathrm{O}$ estudo tem como objetivo avaliar a produtividade e a viabilidade econômica das modalidades de consórcio de milho e $U$. ruziziensis na região noroeste do Paraná. $\mathrm{O}$ experimento foi conduzido em Maringá-PR, em delineamento inteiramente casualizado com cinco tratamentos (milho solteiro; $U$. ruziziensis solteira; milho com U. ruziziensis na entre linha; milho com U. ruziziensis na mesma linha; milho com $U$. ruziziensis em linhas intercaladas) e quatro repetições. Foi analisado o desenvolvimento inicial e produtividade de grãos do milho, e produção de biomassa de milho e U. ruziziensis. Os dados foram submetidos a análise de variância e as médias comparadas pelo teste Tukey com significância de 5\%. No desenvolvimento inicial das plantas de milho não houve diferença significativa em função da consorciação. U. ruziziensis em sistema consorciado apresentou redução na produção de biomassa. O cultivo em linhas intercaladas apresentou produtividade de grãos superior as demais modalidades de consorciação e semelhante ao cultivo de milho solteiro.

Palavras-chave: Biomassa, Produção de grãos, Sistema Plantio Direto, Zea mays. 


\section{Introduction}

The maize (Zea mays) and brachiaria (Urochloa sp.) intercropping is the aim of many studies, focusing on grain production and integrated agricultural production systems. The efficiency of intercropping can be obtained in a short time, related to biomass production, nutrients cycling, weed infestation, nitrogen fertilization efficiency, and inoculation of Azospirillum brasilense without reduction of yield potential of maize (Pacheco et al., 2016; Mechi et al., 2018; Veronezi et al., 2018; Arf et al., 2018; Oliveira et al., 2019).

Cultivating brachiaria (Urochloa ruziziensis) in intercropping systems allows biomass production to successor crops and is beneficial mainly in low soil fertility (Cordeiro et al., 2019; Oligini et al., 2019). The initial development of the forage is slower, allowing the establishment of an annual crop of economic interest without reducing yield potential (Kimecz et al., 2018).

Studies by Arf et al. (2018) show that maize production can be reduced in intercropping. The divergence between results about the effect of intercropping between corn and grasses, as $U$. ruziziensis are related to edaphoclimatic conditions, management, and cultivation practices. In addition, economic aspects must consider defining the efficiency of intercropping Garcia et al. (2012). Thus, regional studies show high importance, characterizing techniques that increase the efficiency of agricultural systems. The present study aimed to evaluate the yield and economic viability of the corn and $U$. ruziziensis intercropping modalities in the northwestern region of Paraná.

\section{Material and Methods}

The study was carried out in the Irrigation Technical Center of the Department of Agronomy belonging to the State University of Maringá, in Maringa - PR - Brazil, at $23^{\circ} 25^{\prime} \mathrm{S}$ and $51^{\circ} 57^{\prime} \mathrm{W}$, and altitude of $542 \mathrm{~m}$. The region has annual precipitation between 1,400 and 1,600 $\mathrm{mm}$, temperature between 21.1 and $22^{\circ} \mathrm{C}$, evapotranspiration of 1,000 to $1,100 \mathrm{~mm}$, and solar radiation of 14,5 to $15 \mathrm{MJ} \mathrm{m}^{-2}$ day $^{-1}$ (Nitsche et al., 2019). During the crop cycle from 10/25/2019 to 03/09/2020, monthly variations of temperature and pluviometry were recorded (Figure 1).

A completely randomized design was adopted with five treatments (Table 1) and four replicates. The experimental plots had $20,25 \mathrm{~m}^{2}$ of the total area and 11 $\mathrm{m}^{2}$ of useful area. The corn hybrid Pioneer 3707 VYH was used. The seeds were treated with a product containing Pyraclostrobin, Methyl thiophanate, and fipronil (1 $\mathrm{g}$ a.i. $\mathrm{kg}^{-1}$ of seeds) and inoculated with Azospirillum brasilense.

The predecessor cultivation of black oat (Avena strigosa) intercropped with oilseed radish (Raphanus sativus L.) produced $2,500 \mathrm{~kg} \mathrm{ha}^{-1}$ of dry matter of remaining straw in the experimental area. Corn was sown (10/25/2019) using a population density of 60,000 $\mathrm{pl} \mathrm{ha}{ }^{-1}$ and $2.7 \mathrm{pl} \mathrm{m}^{-1}$ (Table 1). Forage seeds were sown simultaneously with corn using $10 \mathrm{~kg} \mathrm{ha}^{-1}$ (cultural value of 50\%), which are arranged in different positions relating to maize according to Table 1 .

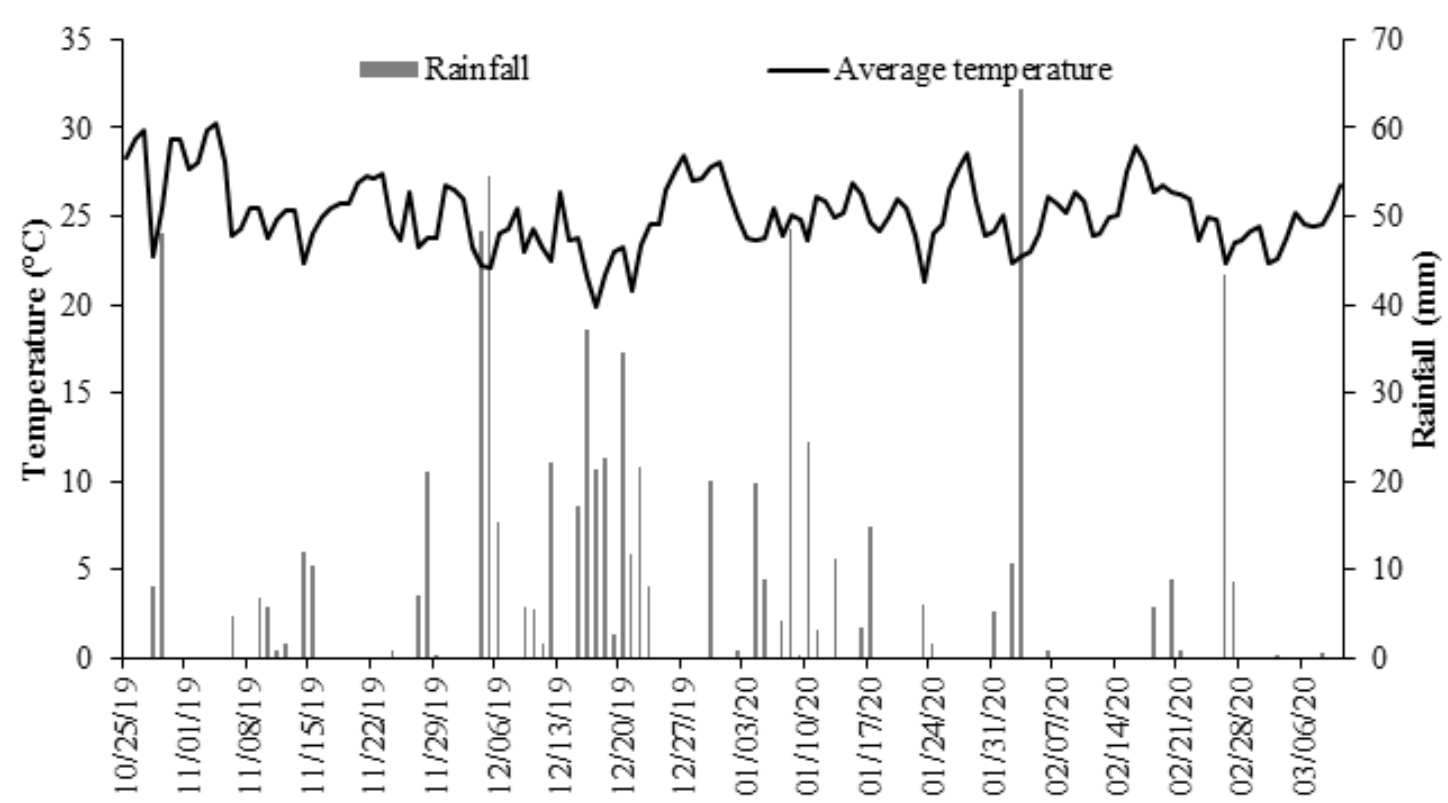

Figure 1. Meteorological data in the period from October 2019 to March 2020, Maringá-PR. Source: INMET (2020). 
Table 1. Configuration of the cultivation system with corn, U. ruziziensis, and intercropping modalities.

\begin{tabular}{cc}
\hline Treatment & Cultivation system \\
\hline 1 & Single corn $^{(1)}$ \\
2 & Single $U$. ruziziensis $^{(2)}$ \\
3 & Corn and ${\text {. ruziziensis intercropping (between rows) }{ }^{(1)}}^{(1)}$ \\
5 & Corn and .ruziziensis intercropping (same row) $^{(1)}$ \\
\hline
\end{tabular}

Spacing: ${ }^{(1)} 0,45 \mathrm{~cm}$ between corn row; ${ }^{(2)} 0,45 \mathrm{~cm}$ between brachiaria row; ${ }^{(3)} 0,7 \mathrm{~cm}$ between corn rows.

The soil in the experimental area is classified as NITOSSOLO VERMELHO distroférrico, corresponding to a Ultisol in the Soil Taxonomy Classification (SANTOS et al., 2018), with clayey texture and $\mathrm{pH}$ (SMP method): 6.4; $\mathrm{Al}: 0 \mathrm{cmol}_{\mathrm{c}} \mathrm{dm}^{-3} ; \mathrm{Al}+\mathrm{H}: 3.66 \mathrm{cmol}_{\mathrm{c}} \mathrm{dm}^{-3}$; Ca: $4.1 \mathrm{cmol}_{\mathrm{c}} \mathrm{dm}^{-3}$; $\mathrm{Mg}: 2.56 \mathrm{cmol}_{\mathrm{c}} \mathrm{dm}^{-3} ; \mathrm{K}: 0.37 \mathrm{cmol}_{\mathrm{c}}$ $\mathrm{dm}^{-3}$; P (Mehlich-I): $3.47 \mathrm{mg} \mathrm{dm}^{-3}$; organic matter: 22.95 $\mathrm{g} \mathrm{dm}^{-3}$, and soil cation exchange capacity: $10.69 \mathrm{cmol}_{\mathrm{c}}$ $\mathrm{dm}^{-3}$. The fertilization at the sowing furrow was carried out with $300 \mathrm{~kg} \mathrm{ha}^{-1}$ of NPK formulation (10:20:20). The topdressing fertilization was carried out with $175 \mathrm{~kg} \mathrm{ha}^{-1}$ of urea (45\% N), according to Pauletti and Motta (2017).

The initial corn development was analyzed in the different intercropping modalities, with the height determination in two evaluations in the vegetative stage. The biomass of corn and $U$. ruziziensis were evaluated with a square of $0.5 \mathrm{~m} \times 0.5 \mathrm{~m}$ randomly launched in the useful area of plots. All plants into the square were collected, weighed in an analytical balance $( \pm 0.001 \mathrm{~g})$, and kept in a forced air circulation oven at $105^{\circ} \mathrm{C}$ until they reached constant weight, then the dry matter was obtained.

The harvest of corn in $2 \mathrm{~m}^{2}$ per experimental parcel was carried out when the grains had $20 \%$ of water content on a wet basis (\%wb), analyzing diameter, length, and the number of rows per spike. The grain mass was determined in analytical balance $( \pm 0.001 \mathrm{~g})$, the grains water content at forced air circulation oven $\left(105^{\circ} \mathrm{C}\right.$ for 24 hours), and adjusted to $14 \% \mathrm{wb}$, estimating the grain yield $\left(\mathrm{kg} \mathrm{ha}^{-1}\right)$. The data were submitted to analysis of variance; the means were compared by the Tukey test at $5 \%$ probability, using the SISVAR software (Ferreira, 2019).

The production cost was calculated according to the CONAB methodology (2010). The price of agricultural machinery and equipment was based on the cost per hour of work, considering the management with sowing, nitrogen fertilization, and application of pesticides. General costs were calculated considering $2 \%$ of expenses with agricultural machinery and equipment. The cost of seeds, fertilizers, and pesticides was based on the purchase price. The cost of harvesting and transport was calculated according to the average cost (9.5\% of production) practiced in the region by producers. The variable cost was calculated by the sum of agricultural machinery and equipment costs, general costs, seeds, fertilizers, pesticides, harvesting, and transport.

Fixed costs were not considered. The variation of land capital and fees depending on the location of the cultivation was considered. The economic balance was calculated according to the financial return from yield and the variable costs of each management condition. Cost values were expressed in dollars, considering the US\$ 1.00 is equivalent to $\mathrm{R} \$ 5.422$.

\section{Results and Discussion}

The analysis of the intercropping in different producing regions allows determining specific difficulties according to edaphoclimatic conditions and growing season, showing results with regional applicability. Significant differences were observed when considering the initial maize development concerning height, with higher plant height in the intercropping with $U$. ruziziensis sown between rows concerning the cultivation of single corn (Table 2).

According to Araújo et al. (2018), corn intercropping reduces production components associated with ear characteristics, like size, number of rows and grains, and grains mass. For variables related to spike traits, the results refer to the number of grains per row, and the diameter of spikes did not show differences among the treatments. However, the intercropping cultivation with interspersed rows produced spikes with a larger length, with significant values and higher than the spikes harvested in the maize and brachiaria intercropping in the same row (Table 2).

It suggests that the sowing position in the corn/brachiaria intercropping differs from features associated with soil cover, luminous interception and nutrients, and water demand, reflecting on the morphological development in both cultivations, consequently influencing the biomass production. In the experimental conditions, there was no significant difference in the corn biomass (Table 3), indicating that the competition for water and nutrients among the brachiaria plants in the row did not influence the performance and yield of the corn plants. 
Table 2. Plant height at the vegetative stage, diameter and length of spikes, and the number of grain rows per spike of corn under different intercropping modalities with U. ruziziensis, Maringá-PR, 2019/2020 harvest.

\begin{tabular}{|c|c|c|c|c|c|}
\hline \multirow[t]{2}{*}{ Treatment } & \multicolumn{2}{|c|}{ Plant height $(\mathrm{cm})$} & \multicolumn{3}{|c|}{ Corn spike } \\
\hline & $36 \mathrm{DAS}^{(1)}$ & $50 \mathrm{DAS}^{(2)}$ & Diameter (mm) & Length $(\mathrm{cm})$ & $\mathrm{N}^{\mathrm{o}}$ of rows \\
\hline Single maize & $57.20 \mathrm{ab}$ & $120.00 \mathrm{~b}$ & $48.74 \mathrm{a}$ & $15.45 \mathrm{ab}$ & $16.27 \mathrm{a}$ \\
\hline Single $U$. ruziziensis & - & - & - & - & - \\
\hline $\mathrm{C}+\mathrm{U}$ (between rows) & $62.03 \mathrm{a}$ & $159.25 \mathrm{a}$ & $48.80 \mathrm{a}$ & $15.66 \mathrm{ab}$ & $15.50 \mathrm{a}$ \\
\hline $\mathrm{C}+\mathrm{U}$ (same row) & $51.44 \mathrm{c}$ & $129.25 \mathrm{~b}$ & $47.33 \mathrm{a}$ & $14.15 \mathrm{~b}$ & $15.20 \mathrm{a}$ \\
\hline $\mathrm{C}+\mathrm{U}$ (interspersed rows) & $55.04 \mathrm{bc}$ & $147.50 \mathrm{ab}$ & $48.80 \mathrm{a}$ & $16.25 \mathrm{a}$ & $15.55 \mathrm{a}$ \\
\hline $\mathrm{CV}(\%)$ & 11.95 & 10.47 & 2.89 & 6.22 & 6.25 \\
\hline
\end{tabular}

*Means followed by the same letters in columns do not show differences between each other by the Tukey test (p<0.05); DAS - Days after sowing; (1) evaluation day 11/30/2019; (2) evaluation day 12/14/2019.

Table 3. Grains yield and production of biomass of corn (DM) and U. ruziziensis on intercropping modalities, Maringá-PR, 20192020 harvest.

\begin{tabular}{llcl}
\hline Treatments & Grain yield $\left(\mathrm{kg} \mathrm{ha}^{-1}\right)$ & Biomass $\left(\mathrm{kg} \mathrm{h}^{-1}\right)$ \\
\cline { 3 - 4 } & & Corn & Brachiaria \\
\hline Single corn & $10,099 \mathrm{a}$ & $23,143 \mathrm{a}$ & - \\
Single $U$. ruziziensis & - & - & $4,991 \mathrm{a}$ \\
$\mathrm{C}+\mathrm{U}$ (between rows) & $9,157 \mathrm{~b}$ & $19,869 \mathrm{a}$ & $527 \mathrm{c}$ \\
$\mathrm{C}+\mathrm{U}$ (same row) & $9,492 \mathrm{~b}$ & $20,104 \mathrm{a}$ & $1,097 \mathrm{~b}$ \\
$\mathrm{C}+\mathrm{U}$ (interspersed rows) & $9,852 \mathrm{a}$ & $21,919 \mathrm{a}$ & $930 \mathrm{~b}$ \\
\hline $\mathrm{CV}(\%)$ & 5.57 letter in the columns do not differ from each other by Tukey test (p<0.05).
\end{tabular}

The biomass production of $U$. ruziziensis was higher in the single cultivation than brachiaria in intercropping systems (Ribeiro et al., 2018). In the intercropping conditions, in interspersed rows and/or in the same row, the brachiaria biomass production was higher than the $U$. ruziziensis sowing between the corn rows (Table 3).

Developed studies in southwestern Paraná with intercropping of corn with different forage species did not show significant differences in the corn yield. The intercropping with $U$. brizantha and $U$. ruziziensis showed higher biomass production (Oligini et al., 2019). When assessing the intercropping of corn with Brachiaria brizantha cv. Marandu, they concluded that there was no interference in the maize yield. The corn showed a higher accumulation of nutrients in the remaining straw in the consortium system. (Arf et al., 2018).

Studying the corn intercropping with different species of forages (Santos et al., 2017) observed that
Urochloa ruziziensis did not affect the grain yield. According to Makino et al. (2019), the population arrangement of corn in the intercropping system shows a stronger influence on yield concerning the presence of brachiaria. Pereira et al. (2018) observed higher increments in the corn grain yield in the row spacing of $0.90 \mathrm{~m}$ concerning the $0.45 \mathrm{~m}$.

Queiroz et al. (2016) obtained higher yield and biomass production of $U$. ruziziensis when the corn was sown with a row spacing of $0.9 \mathrm{~m}$ and the $U$. ruziziensis in the same rows, similar in this study. Araújo et al. (2018), when analyzing the spacing of corn sowing and concluded that the first ear insertion height was higher in the spacing of $0.5 \mathrm{~m}$, without interfering in the yield components, while the largest dry matter production of $U$. brizantha was obtained in the spacing of $0.7 \mathrm{~m}$. When analyzing the corn morphological components and brachiaria, there was variation in the economic margin between the intercropping modalities (Table 4). 
Table 4. Economic analysis (US\$ ha ${ }^{-1}$ ) of intercropped and Urochloa ruziziensis cultivation, Maringá-PR, 2019/2020.

\begin{tabular}{|c|c|c|c|c|c|}
\hline \multirow{2}{*}{ Productive variable/economic } & \multicolumn{5}{|c|}{ Treatment } \\
\hline & 1 & 2 & 3 & 4 & 5 \\
\hline Machinery and equipment expenses & 54.12 & 17,52 & 54.12 & 54.12 & 54.12 \\
\hline General expenses ${ }^{(1)}$ & 1.08 & 0.35 & 1.08 & 1.08 & 1.08 \\
\hline Seed & 124.03 & 2.73 & 126.77 & 126.77 & 126.77 \\
\hline Fertilizer & 82.34 & 33.47 & 82.34 & 82.34 & 82.34 \\
\hline Agrochemicals & 67.37 & 16.28 & 67.37 & 67.37 & 67.37 \\
\hline Harvesting and transportation ${ }^{(2)}$ & 215.28 & - & 195.20 & 202.34 & 210,02 \\
\hline Total variable cost & 544.22 & 70.35 & 526.88 & 534.02 & 541.7 \\
\hline Yield & 168.32 & - & 152.62 & 158.20 & 164.20 \\
\hline Price per bag ${ }^{(3)}$ & 13.46 & - & 13.46 & 13.46 & 13.46 \\
\hline Economic return & $2,265.58$ & - & $2,054.26$ & $2,129.37$ & $2,210.13$ \\
\hline Profit margin $^{(4)}$ & $1,721.36$ & -70.35 & $1,527.38$ & $1,595.35$ & $1,668.43$ \\
\hline
\end{tabular}

Analyzing the economic scenario of crops and considering only variable costs, we checked that in the treatment 5 (maize/brachiaria $U$. ruziziensis in intercalated rows), the profit margin was $3.67 \%$ lower compared with the single cropping, diverging from the obtained by Garcia et al. (2012) that reported that the intercropping showed higher values than single cultivation of corn, indicating the economic importance of intercropping of cultivation for production system and greater profit for the producer. Still, without interfering in the corn yield, the intercropping with $U$. ruziziensis showed to be more economically viable to another forage species. In this study, the economic margin of brachiaria in the short term was lower, although the intercropping generated benefits in the harvest of the successor production system.

The corn intercropped with $U$. ruziziensis, as another species like Crotalaria juncea L., needs adequate management to minimize the effects of competition in the crop yield and consequently in the monetary return. Concerning the single cultivation of $U$. ruziziensis, biomass production generated a cost of US\$14,09 $\mathrm{Mg}^{-1}$ DM.

Considering the productive and economic scenario, the utilization of the corn and $U$. ruziziensis intercropping in interspersed rows, row spacing of $0,45 \mathrm{~m}$, showed results closest to single cultivation of corn, and shows be a better option of intercropping to the cultivation conditions in the northwestern Parana.

\section{Conclusions}

The biomass production of $U$. ruziziensis is reduced in intercropping with corn compared to the forage in the single cultivation system. Cultivation of corn intercropped with interspersed rows showed a similar yield to the single cultivation system and higher than intercropping between rows or in the same row

\section{Authors' Contribution}

Gustavo Soares Wenneck contributed to writing, statistical analysis, interpretation of results, and economic data analysis. Reni Saath to the setup of the experiment, technical supervision, and revision. Larissa Leite de Araujo contributed to the collection of data in the field and the writing of the manuscript in the English language. Gustavo Lopes Pereira contributed to economic data analysis and writing of the manuscript in the English language. Giovanna Gabriela Ferreira de Oliveira contributed to crop management and collection of data. Nathália de Oliveira Sá contributed to crop management and collection of data. Camila de Souza Volpato contributed to crop management and the collection of data.

\section{Acknowledgments}

To Coordenação de Aperfeiçoamento de Pessoal de Nível Superior - Brazil (CAPES); Conselho Nacional de Desenvolvimento Científico e Tecnológico (CNPq); Fundação Araucária de Apoio ao Desenvolvimento Científico e Tecnológico do Estado do Paraná and Universidade Estadual de Maringá.

\section{Bibliographic References}

Araújo, L.S., Branquinho, J.A.S., Silveira, P.M., Silva, L.G.B., Valente, M.S., Siqueira, M.V. R., Cunha, P.C.R. 2018. Produtividade de milho solteiro e consorciado com Urochloa brizantha em dois espaçamentos de plantio no sudeste de Goiás. Revista Agrarian, 11 (42), 307-318. DOI: https://doi.org/10.30612/agrarian.v11i42.4335. 
Arf, O., Meirelles, F.C., Portugal, J.R., Buzetti, S., Sá, M.E., Rodrigues, R.A.F. 2018. Benefícios do milho consorciado com gramínea e leguminosas e seus efeitos na produtividade em sistema plantio direto. Revista Brasileira de Milho e Sorgo, 17 (3), 431-444.

CONAB. COMPANHIA NACIONAL DE ABASTECIMENTO. 2010. Ministério da Agricultura, Pecuária e Abastecimento. Custos de produção agrícola: a metodologia da Conab. Brasília, Ministério da Agricultura, Pecuária e Abastecimento, 60 p.

Cordeiro, C.F.S., Echer, F.R., Pires, L.H.T., Creste, J.E. 2019. Productivity of castor bean plants intercropped at diferente plant densities with Urochloa ruziziensis. Revista Brasileira de Engenharia Agrícola e Ambiental, 23 (2), 109-113. DOI: https://doi.org/10.1590/1807-1929/agriambi.v23n2p109-113.

Ferreira, D.F. 2019. SISVAR: a computer analysis system to fixed effects Split plot type designs. Revista Brasileira de Biometria, 37 (4), 529-535. DOI: https://doi.org/10.28951/rbb.v37i4.450.

Garcia, C.M.D.P., Andreotti, M., Tarsitano, M.A.A., Teixeira Filho, M.C.M., Lima, A.E.S., Buzetti, S. 2012. Análise econômica da produtividade de grãos de milho consorciado com forrageiras dos gêneros Brachiaria e Panicum em sistema plantio direto. Ceres, 59 (2), 157-163. DOI: https://doi.org/10.1590/S0034-737X2012000200002

INMET. INSTITUTO NACIONAL DE METEOROLOGIA. 2020. Sistema de Suporte à Decisão na Agropecuária (SISDAGRO). http://sisdagro.inmet.gov.br/sisdagro/app/index. (acessado 30 de março de 2021).

Kimecz, A.M., Silva, W.J.C., Machado, D.H., Stein G., Dalchiavon, F.C. 2018. Agronomic performance of sunflower intercropped with Urochloa ruzizizensis. Científica, 46 (4), 353-358. DOI: http://dx.doi.org/10.15361/19845529.2018v46n4p353-358.

Makino, P.A., Ceccon, G., Fachinelli, R. 2019. Produtividade e teor de nutrientes em populações de milho safrinha solteiro e consorciado com braquiária. Revista Brasileira de Milho e Sorgo, 18 (2), 206-220. DOI: https://doi.org/10.18512/19806477/rbms.v18n2p206-220.

Mechi, I.A., Santos, A.L.F., Ribiro, L.M., Ceccon, G. 2018. Infestação de plantas daninhas de difícil controle em função de anos de consórcio milho-braquiária. Revista de Agricultura Neotropical, 5 (3), 49-54. DOI: https://doi.org/10.32404/rean.v5i3.1642.

Nitsche, P.R., Caramori, P.H., Ricce, W.S., Pinto, L.F.D. 2019. Atlas Climático do Estado do Paraná. Londrina, IAPAR.
Oligini, K.F., Salomão, E.C., Batista, V.V., Link, L., Adami, P.F., Sartor, L.R. 2019. Produtividade de milho consorciado com espécies forrageiras no sudoeste do Paraná. Revista Agrian, 12 (46), 434-442. DOI: https://doi.org/10.30612/agrarian.v12i46.8705.

Oliveira, S.M., Almeida, R.E.M., Pierozan Junior, C., Reis, A.F. B., Souza, L.F.N., Favarin, J. L. 2019. Contribution of corn intercropped with Brachiaria species to nutrient cycling. Pesquisa Agropecuária Tropical, 49, e55018. DOI: https://doi.org/10.1590/1983-40632019v4955018.

Pacheco, L.P., Petter, F.A., Soares, L.S., Silva, R.F., Oliveira, J.B.S. 2016. Sistemas de produção no controle de plantas daninhas em culturas anuais no Cerrado Piauiense. Revista Ciência Agronômica, 47 (3), 500-508. DOI: https://doi.org/10.5935/1806-6690.20160060.

Pauletti, V., Motta, A.C.V. 2017. Manual de adubação e calagem para o estado do Paraná. Curitiba, SBCS/Nepar.

Pereira, F., Rômulo, V., Chioderoli, C. A., Albiero, D., Silva, A. O., Nascimento, E. M. S., Santos, P. R. A. 2018. Desempenho agronômico da cultura do milho sob diferentes arranjos espaciais no nordeste brasileiro. Revista Brasileira de Agricultura Irrigada, 12 (5), 2976-2983. DOI: https://doi.org/10.7127/rbai.v12n500946.

Queiroz, R.F., Chioderoli, C.A., Furlani, C.E.A., Holanda, H.V., Zerbato, C. 2016. Maize intercropped with Urochloa ruziziensis under no-tillage system. Pesquisa Agropecuária Tropical, 46 (3), 238-244. DOI: https://doi.org/10.1590/1983$40632016 \mathrm{v} 4640464$.

Ribeiro, L.M., Leite, E.M., Ceccon, G. 2018. Interferência de culturas anuais no crescimento inicial de brachiaria ruziziensis. Revista de Agricultura Neotropical, 5 (3), 70-75. DOI: https://doi.org/10.32404/rean.v5i3.2077.

Santos, H.G., Jacomine, P.K.T., Anjos, L.H.C., Oliveira, V.Á., Lumbreras, J.F., Coelho, M.R., Almeida, J.A., Araújo Filho, J.C., Oliveira, J.B., Cunha, T.J.F. 2018 Sistema Brasileiro de Classificação de Solos. 5. ed. Rio de Janeiro, Embrapa Solos, 353 p.

Santos, P.R.A., Chioderoli, C.A., Loureiro, D.R., Araújo Nicolau, F.E., Oliveira, J.L.P., Queiroz, R.F. 2017. Características morfológicas e produtivas do milho no consórcio com forrageiras em diferentes épocas de semeadura. Revista Brasileira de Agricultura Irrigada, 11 (7), 20-31. http://dx.doi.org/10.7127/RBAI.V11N700678.

Veronezi, S.D.F., Ribeiro, L.M., Ceccon, G. 2018. Uso de Azospirillum brasilense em milho safrinha solteiro e consorciado com Brachiaria ruziziensis. Brazilian Journal of Biosystems Engineering, 12 (4), 349-360. DOI: http://dx.doi.org/10.18011/bioeng2018v12n4p349-360 